\title{
Analysis of the implementation of changes on an assembly line in the auto industry
}

\author{
Monica BÂLDEA*, Ancuța BĂLTEANU \\ University of Pitesti, Pitesti, Romania \\ ${ }^{*}$ Corresponding author e-mail: monica.baldea@upit.ro \\ Article history \\ Received 15.07.2019 \\ Accepted 20.09.2019 \\ DOI https://doi.org/10.26825/bup.ar.2019.003
}

\begin{abstract}
The present paper aims to present the solving of problems registered in an assembly production line for a given product, problems that led to the appearance of defects identified by the customer. It starts from the analysis of the functional and quality indicators of the assembly line. Also, the complaints coming from the client are analyzed for 2 types of defects that appeared in the assembly process, using the AMDEC method. It is also analyzed the working time for each workstation, in order to be able to identify the possible blocking position. It then proceeds to the establishment of a revised AMDEC, from which it is expected to establish corrective actions and find solutions. Next, the action plan for the process is established, following the risk analysis. The proposed solutions are implemented, in order to be able to evaluate their impact and the changes that have occurred in the production flow. Finally, after analyzing the obtained results, it is found that the complaints from the customer - on the one hand - were eliminated and an increase in the production capacity of the line was obtained - on the other, both results contributing to the increase of the profit of the organization.
\end{abstract}

Keywords: quality, assembly, AMDEC, workstation, production flow.

\section{Introduction}

The product studied in this paper will be referred to as product X. Product X is obtained as part of a production process, which is a technological assembly process, which is composed of a series of operations. These operations aim at the placement and fixing of various components, in order to obtain the final system that makes up the product $X$. The form of production organization in this case is the flow organization, on the assembly line, with specialized positions for performing certain assembly operations, the final purpose being the product of $X$ [1]. The characteristics of the assembly line are [5]:

- the division of the assembly process is on 6 positions - plus final control - approximately equal in terms of time, respectively of work volume;

- the grouping of operations by stations was not carried out taking into account the rhythm of the line;

- the specialization of the workstations is achieved by training the operators;

- multiple operations are performed at each station; 
The analysis of the working time for each workstation is highlighted in table 3 , which shows that the workstation 3 is a blocking station [1].

Table 3 Initial analysis of working time

\begin{tabular}{|c|c|c|c|c|c|c|c|}
\hline No. & workstation & workstation & workstation & workstation & workstation & workstation & Control \\
workstation & 1 & 2 & 3 & 4 & 5 & 6 & \\
\hline Time $(\mathrm{sec})$ & 42 & 43 & 54 & 43 & 45 & 43 & 48 \\
\hline
\end{tabular}

\section{Implementation of the solution on the assembly line for defection elimination}

The existing AMDEC has been revised. The AMDEC analysis must necessarily contain a good definition of the actions, the dates of implementation, as well as the persons responsible for the implementation of the actions - tables $4 \mathrm{a}$ and 4.b.

Table 4.a revised AMDEC (selection)

\begin{tabular}{|c|c|c|c|c|c|c|}
\hline Defect & Effect & $\begin{array}{c}\text { Corrective } \\
\text { actions }\end{array}$ & $\begin{array}{c}\text { Date of } \\
\text { planning }\end{array}$ & $\begin{array}{c}\text { Date of } \\
\text { achievement }\end{array}$ & Pilot & $\begin{array}{l}\text { The result of } \\
\text { the actions }\end{array}$ \\
\hline $\begin{array}{l}\text { missing screws } \\
\text { no. total } \\
\text { screws }\end{array}$ & $\begin{array}{l}\text { The landmark is operable, } \\
\text { functionally, it can } \\
\text { degrade, } \\
\text { nonconforming product }\end{array}$ & \multirow{2}{*}{$\begin{array}{l}\text { Implementation } \\
\text { of a permanent } \\
\text { semi-casing } \\
\text { assembly } \\
\text { solution: } \\
\text { ultrasonic and } \\
\text { thermal welding } \\
\text { machine }\end{array}$} & 08.2019 & 09.2019 & \multirow{2}{*}{$\begin{array}{l}\text { Project } \\
\text { engineer } \\
\text { and } \\
\text { methods } \\
\text { engineer }\end{array}$} & $\begin{array}{c}\text { Solved } \\
\square\end{array}$ \\
\hline $\begin{array}{l}\text { removing } \\
\text { screws } \\
\text { in the open } \\
\text { area }\end{array}$ & $\begin{array}{c}\text { Inoperable landmark, } \\
\text { reduced performance level, } \\
\text { without affecting the safety } \\
\text { of the product. }\end{array}$ & & 08.2019 & 09.2019 & & $\begin{array}{c}\text { Solved } \\
\square\end{array}$ \\
\hline
\end{tabular}

Table 4.a revised AMDEC (selection)

\begin{tabular}{|c|c|c|c|c|c|c|}
\hline Defect & Effect & Corrective actions & $O$ & $S$ & $D$ & $R P N$ \\
\hline $\begin{array}{l}\text { missing screws } \\
\text { no. total screws }\end{array}$ & $\begin{array}{l}\text { The landmark is operable, } \\
\text { functionally, it can degrade, } \\
\text { nonconforming product }\end{array}$ & \multirow{2}{*}{$\begin{array}{l}\text { Implementation of a } \\
\text { permanent semi-casing } \\
\text { assembly solution: } \\
\text { ultrasonic and thermal } \\
\text { welding machine }\end{array}$} & 3 & 7 & 2 & 42 \\
\hline $\begin{array}{l}\text { Scăpare șuruburi } \\
\text { în zona deschisă }\end{array}$ & $\begin{array}{l}\text { Reper inoperabil, reducere nivel performanță, } \\
\text { fără afectarea siguranței produsului. }\end{array}$ & & 3 & 6 & 2 & 36 \\
\hline
\end{tabular}

The action plan defined for the process following the risk analysis, is the implementation of a permanent solution for the assembly of the semi-carcasses, namely by ultrasonic and thermal welding. This solution involves the introduction into the process of a new machine, a welding machine.

The ultrasonic and thermal welding machine was designed to be integrated into the assembly production line studied - figure 2.a. The points impacted by this modification of the assembly process are those presented in figure 2.b.
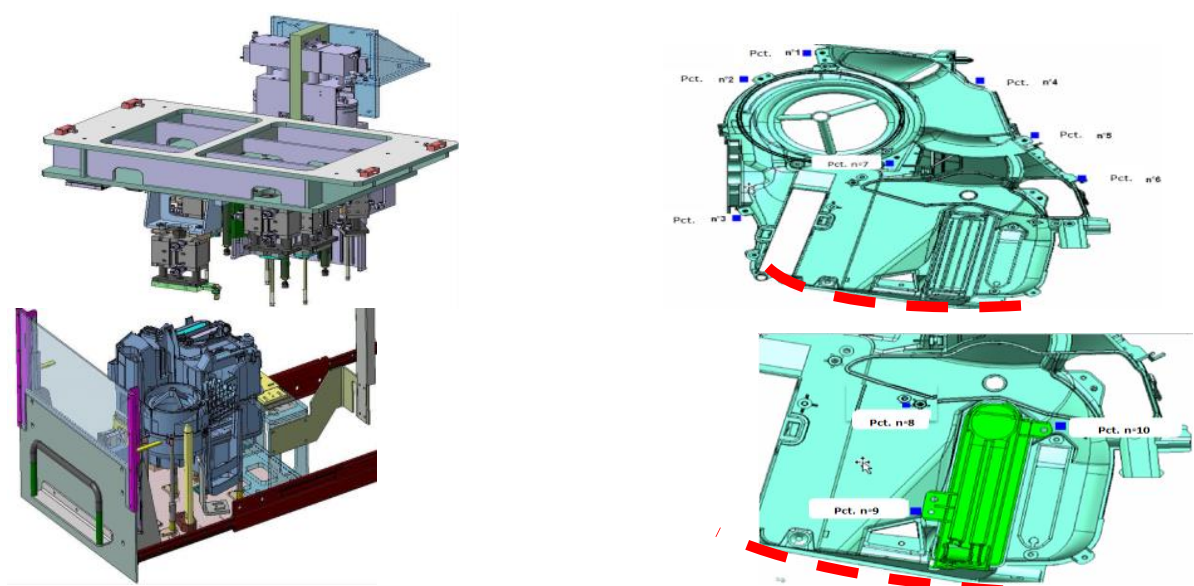

Figure 2. Applying the solution for the assembly line

a. ultrasonic and thermal welding machine

b. weld points

At the beginning of the implementation of the new welding machine in the assembly line of product $\mathrm{X}$, the first problems were identified. These problems were aimed - mainly [3]: 
$\square$ the incorrect position of the operator when loading and unloading the part from the welding machine,

$\square$ rotating the operator by 90 degrees at each operation to perform the same movements.

The solution found to solve these problems is to implement an automatic robotic mechanism for loading / unloading the welding machine - Figure 3 [6].
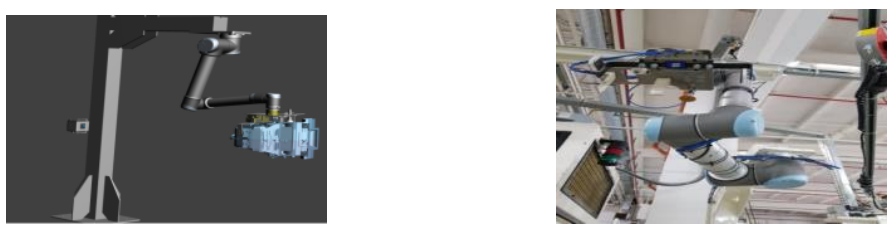

Figure 3 Automatic robotic mechanism implemented

The automatic robotic mechanism implemented, in addition to the ergonomic advantage, also contributed to the reduction of the cycle time from item 3 - table 5. Thus, after the sled reaches the welding station, the piece is loaded / unloaded by the automatic robotic mechanism, and the operator while performing these operations - will go to the next item, to perform the following operations. A comparison between the two situations was made in Figure 4.

Table 5 Analysis of the modified working time

\begin{tabular}{|c|c|c|c|c|c|c|c|}
\hline $\begin{array}{c}\text { No. } \\
\text { workstation }\end{array}$ & $\begin{array}{c}\text { workstation } \\
1\end{array}$ & $\begin{array}{c}\text { workstation } \\
2\end{array}$ & $\begin{array}{c}\text { workstation } \\
3\end{array}$ & $\begin{array}{c}\text { workstation } \\
4\end{array}$ & $\begin{array}{c}\text { workstation } \\
5\end{array}$ & $\begin{array}{c}\text { workstation } \\
6\end{array}$ & Control \\
\hline Time $(\mathrm{sec})$ & 42 & 43 & 49 & 47 & 45 & 43 & 48 \\
\hline
\end{tabular}

Figure 4. Comparison between working time in the 2 situations

In workstation 3 the following modifications of the operations performed [4] took place:

- loading of the welding machine by the automatic robotic mechanism on the sled on the support of the welding machine;

- the assembly of 2 semi-finished products by thermal and ultrasonic welding;

- unloading of the welding machine by the automatic robotic mechanism from the back of the welding machine back on the sled;

- moving the sled to the next workstation;

- clips the clamping assembly operation that was initially performed in this workstation, was transferred to the next workstation, namely to station 4;

- the interval between 2 successive pieces is now $49 \mathrm{sec}$. compared to $54 \mathrm{sec}$. initially, so a 5 sec reduction was obtained.

The indicators of the assembly line after the improvement are - table 6:

Table 6 Assembly line indicators in the modified situation

\begin{tabular}{|c|c|c|c|c|c|c|c|}
\hline \multicolumn{8}{|c|}{ Functional indicators of the line } \\
\hline $\begin{array}{c}\text { No. } \\
\text { operators }\end{array}$ & $\begin{array}{l}\text { Td-time } \\
\text { available }\end{array}$ & $\underset{\text { quantity }}{Q-}$ & $T-t a c t$ & $\begin{array}{c}\text { KOSU - cycle } \\
\text { time }\end{array}$ & $\begin{array}{c}C P-\max . \\
\text { capacity of the } \\
\text { line }\end{array}$ & $\begin{array}{l}G_{i l} \text {. degree of } \\
\quad \text { loading }\end{array}$ & $\begin{array}{c}P- \\
\text { workstation } \\
s\end{array}$ \\
\hline [pers.] & {$[\mathrm{min} / \mathrm{ch}]$} & [pieces/ch] & $\begin{array}{c}\text { [min/ } \\
\text { pieces] }\end{array}$ & {$[\mathrm{min} / \mathrm{piece}]$} & [pieces /year] & $\%$ & - \\
\hline $\begin{array}{l}\text { Min } 1 \\
\text { Max } 6\end{array}$ & 450 & $\begin{array}{c}\text { Min } 86 \\
\text { Max } 540\end{array}$ & 0,833 & $\begin{array}{l}\text { Min } 0,833 \\
\operatorname{Max} 5,233\end{array}$ & 456.840 & 90 & $6+1$ \\
\hline \multicolumn{8}{|c|}{ Line quality indicators } \\
\hline \multicolumn{4}{|c|}{$R c$ - customer complaints } & \multicolumn{4}{|c|}{$T L R$ - total waste off the line (target) } \\
\hline \multicolumn{4}{|c|}{ [complaints/year] } & \multicolumn{4}{|c|}{ [pieces /work shift] } \\
\hline \multicolumn{4}{|c|}{0} & \multicolumn{4}{|c|}{0} \\
\hline
\end{tabular}




\section{Results analysis}

The comparison of the initial situation in which the assembly line was located and the one in which the proposed modifications were introduced will be carried out from the organizational, functional and quality indicators point of view.

Thus, from the organizational point of view, in the improved situation the following changes have taken place:

$\square$ a new machine, namely thermal and ultrasonic welding machine, was introduced in workstation 3;

$\square$ an automatic robotic mechanism for loading / unloading the welding machine, necessary for performing the operations of the manipulated subassemblies, was introduced in the workstation 3 ;

$\square$ the operations from workstation 3 were reorganized by: performing the thermal and ultrasonic welding by the thermal and ultrasonic machine and introducing the manipulation operations performed by the automatic robotic mechanism - loading / unloading;

$\square$ the operations from workstation 4 were reorganized by transferring the assembly operation via clip - from workstation 3 where it was initially performed. Thus, the working time for this operation increased by 4 seconds, because this operation did not exist in the initial situation in the workstation 4.

From a functional point of view, the indicators associated with the 2 situations are presented in table 7 .

Table 7 Evolution of the functional indicators of the assembly line

\begin{tabular}{|c|c|c|c|c|c|c|c|c|}
\hline & \multicolumn{8}{|c|}{ Functional indicators of the line } \\
\hline \multirow[t]{2}{*}{$\begin{array}{l}\text { Asse } \\
\text { mbly } \\
\text { type }\end{array}$} & $\begin{array}{c}\text { No. } \\
\text { operator } \\
s\end{array}$ & $\begin{array}{l}\text { Td-time } \\
\text { available }\end{array}$ & $Q$ - quantity & $T-t a c t$ & $\begin{array}{l}\text { KOSU - } \\
\text { cycle time }\end{array}$ & $\begin{array}{c}C P-\max . \\
\text { capacity of the } \\
\text { line }\end{array}$ & $\begin{array}{c}G_{i l} \text {-degree } \\
\text { of loading }\end{array}$ & $\begin{array}{c}P- \\
\text { workstatio } \\
\text { ns }\end{array}$ \\
\hline & [pers.] & {$[\mathrm{min} / \mathrm{ch}]$} & [pieces/ch] & $\begin{array}{c}\text { [min/ } \\
\text { pieces] }\end{array}$ & {$[\mathrm{min} / \mathrm{piece}]$} & [pieces /year] & $\%$ & - \\
\hline \multirow[t]{2}{*}{ screw } & Min 1 & \multirow{2}{*}{450} & Min 85 & \multirow{2}{*}{0,9} & Min 0,9 & \multirow{2}{*}{342.630} & \multirow{2}{*}{90} & \multirow{2}{*}{$6+1$} \\
\hline & $\operatorname{Max} 7$ & & Max 405 & & Max 6,33 & & & \\
\hline \multirow{2}{*}{$\begin{array}{l}\text { weldi } \\
\text { ng }\end{array}$} & Min 1 & \multirow{2}{*}{450} & Min 86 & \multirow{2}{*}{0,833} & Min 0,833 & \multirow{2}{*}{456.840} & \multirow{2}{*}{90} & \multirow{2}{*}{$6+1$} \\
\hline & Max 6 & & Max 540 & & $\operatorname{Max} 5,233$ & & & \\
\hline
\end{tabular}

The analysis of the functional indicators of the assembly line shows the following changes:

$\square$ the maximum number of operators decreased from 7 to 6 , so a reduction was obtained with 1 operator / exchange of work;

$\square$ the maximum quantity of products realized on the exchange of work has registered an increase from 405 pcs / exchange of work 540 pcs / exchange of work with +135 pcs / exchange of work;

$\square$ the tact of the line decreased from $0.9 \mathrm{~min} / \mathrm{pcs}$ to $0.833 \mathrm{~min} / \mathrm{pcs}$ with $-0.067 \mathrm{~min} / \mathrm{pcs}$;

$\square$ the KOSU indicator fell from $6.33 \mathrm{~min} / \mathrm{pcs}$ to $5.233 \mathrm{~min} / \mathrm{pcs}$, so a reduction of 1,097 was obtained for the maximum number of operators;

$\square$ the production capacity of the assembly line increased from $342,630 \mathrm{pcs} /$ year to $456,840 \mathrm{pcs} /$ year, so it increased by 114,210 pcs / year.

From the point of view of quality indicators, the results of the 2 situations are presented in table 8 .

Table 8 Evolution of the quality indicators of the assembly line

\begin{tabular}{|c|c|c|c|}
\hline Assembly type & $R c$ - customer complaints & $T L R$ - total waste off the line (target) & $\begin{array}{c}R P N \\
\text { [Defect 1 \& Defect 2] }\end{array}$ \\
\hline & [complaints/year] & [pieces /work shift] & [point] \\
\hline screw & 9 & 9 & $84 \& 144$ \\
\hline & 0 & 0 & $42 \& 32$ \\
\hline
\end{tabular}

The analysis of the quality indicators of the assembly line shows the following changes [2]:

$\square$ the Rc value respectively of the complaints from the client decreased from 9 complaints / year to 0 complaints / year, so all the complaints from the client could be eliminated;

$\square$ the TLR value of the total number of rejects on the line also decreased from 9 pieces / work exchange to 0 pieces / work exchange, so all the rejects could be eliminated; 
$\square$ the value of the RNP dropped significantly from 84 points to 42 points for Defect 1 , so by 42 points for Defect 1;

$\square$ the value of the RNP dropped significantly from 144 points to 32 points for Defect 2, thus 112 points for Defect 2.

\section{Conclusions}

As a first conclusion of the modifications and reorganizations carried out, it can be seen that a workstation 3 has been automated, eliminating certain manual assembly operations, thus eliminating two of the defects identified in the AMDEC analysis.

A second conclusion concerns the many advantages that this solution brings, namely:

$\square$ the quality of the assembly subsystem obtained for the screw operation;

$\square$ during the shorter cycle;

$\square$ improving the ergonomics of the workstation 3;

$\square$ continuity without bottlenecks of the flow of assembly of the obtained subsystem;

$\square$ synchronization of the assembly process, therefore balancing the assembly line;

$\square$ performing this operation on a single machine;

$\square$ eliminating an operator, thus reducing costs;

$\square$ area eliminating expectations;

$\square$ removing a certain number of screws from the composition of the assembly subsystem;

$\square$ lowering the RPN.

In the end, it can be considered that the implementation of the automatic robotic mechanism and the reorganization of the operations from workstation 3 and from workstation 4 ultimately led to the elimination of the complaints coming from the client - on the one hand - but also to the increase of the production capacity of the line - on the other hand, both results contributing to increase the profit of the organization.

\section{References}

[1] Bălteanu A., Băldea M., Applying a performance management by eliminating a post blocker, Management and Economic Engineering, 6th International Management Conference "Performance management or Management Performance?", Cluj-Napoca, Romania, ISI Web of Knowledge Proceedings Database, 2018.

[2] Oke, S.A., An analytical model for the optimisation of maintenance profitability, International Journal of Productivity and Performance Management, Vol. 54, No. 2, pp. 113 - 136., 2005.

[3] Pyzdek, T., Keller,. The Handbook for Quality Management: A Complete Guide to Operational Excellence, 2nd ed. New-York: Mc.Graw-Hill, Inc., 2013.

[4] Rachid Chaib, A., Bellaouar, M., Benidir, I., For better control of the availability of the industrial equipments, vol 11, no 1(28), March, pp. 7-10, 2010.

[5] Rădulescu, C., et Co, Planificarea și conducerea proiectelor, UT Press, Cluj-Napoca, 2017.

[6] Sondermann-Wolke, M., Tichy, S., Holscher, G., Component-based hazard analysis for mechatronic systems, PR of ISORCW, no. 11, pp. 80-87, 2011.

[7] Verzea I., Luca G., Managementul tripletei producție - calitate - mentenanță prin metoda AMDEC, Ed. Performantica, 2013. 